Improvements in OA signs and symptoms in response to valdecoxib were dose-dependent, with the greatest improvements in primary efficacy measures observed at $5 \mathrm{mg}$ BID, $10 \mathrm{mg}$ QD, and $10 \mathrm{mg}$ BID, compared with placebo ( $\mathrm{p}<=0.004$ ). Valdecoxib doses of $5 \mathrm{mg}$ BID, $10 \mathrm{mg}$ QD, and $10 \mathrm{mg}$ BID were also as effective as naproxen $500 \mathrm{mg}$ in the treating signs and symptoms of OA. There were no statistically significant differences between any of the treatment groups in the number of adverse events or in vital signs or clinical laboratory measurements.

\begin{tabular}{|c|c|c|}
\hline \multicolumn{3}{|c|}{ Abstract OP0048 Table 1} \\
\hline & $\begin{array}{l}\text { Least Square Mean Change } \\
\text { from Baseline at Week } 2\end{array}$ & $\begin{array}{l}\text { Least Square Mean Change } \\
\text { from Baseline at Week } 6\end{array}$ \\
\hline Placebo & $-11.46^{*}$ & $-10.44^{*}$ \\
\hline $\begin{array}{l}\text { Valdecoxib } 0.5 \\
\mathrm{mg} \text { BID }\end{array}$ & $-13.84^{*}$ & $-15.74^{*}$ \\
\hline $\begin{array}{l}\text { Valdecoxib } 1.25 \\
\mathrm{mg} \text { BID }\end{array}$ & $-19.09^{* *}$ & $-24.32^{* *}$ \\
\hline $\begin{array}{l}\text { Valdecoxib } 2.5 \\
\mathrm{mg} \text { BID }\end{array}$ & $-24.30^{* *}$ & $-28.08^{* *}$ \\
\hline $\begin{array}{l}\text { Valdecoxib } 5 \mathrm{mg} \\
\text { BID }\end{array}$ & $-28.12^{* *}$ & $-29.42^{* *}$ \\
\hline $\begin{array}{l}\text { Valdecoxib } 10 \\
\mathrm{mg} \text { QD }\end{array}$ & $-27.77^{* *}$ & $-29.50^{* *}$ \\
\hline $\begin{array}{l}\text { Valdecoxib } 10 \\
\text { mg BID }\end{array}$ & $-30.28^{* *}$ & $-29.24^{* *}$ \\
\hline $\begin{array}{l}\text { Naproxen } 500 \\
\text { mg BID }\end{array}$ & $-27.76^{* *}$ & $-30.05^{* *}$ \\
\hline
\end{tabular}

Conclusion Valdecoxib is an effective therapy among patients with symptomatic $\mathrm{OA}$ of the knee. Valdecoxib doses of $5 \mathrm{mg}$ BID, $10 \mathrm{mg}$ QD, and $10 \mathrm{mg}$ BID are maximally efficacious, as they are superior to placebo and comparable to naproxen 500 mg BID in all primary efficacy measures. Valdecoxib is well tolerated at all doses.

Sponsored by Pharmacia Corporation and Pfizer, Inc.

\section{OP0049 A POOLED INDEX TO ASSESS SEVERITY OF OSTEOARTHRITIS OF THE HIP OR KNEE. PERFORMANCE IN A RANDOMISED, DOUBLE BLIND, MULTICENTER, CROSSOVER CLINICAL TRIAL OF DICLOFENACI MISOPROSTOL (ARTHROTEC) COMPARED TO ACETAMINOPHEN IN PATIENTS WITH OSTEOARTHRITIS OF THE HIP OR KNEE}

T Pincus, T Sokka. Division of Rheumatology, Vanderbilt University, Nashville, USA

\subsection{6/annrheumdis-2001.416}

Background A pooled index of various measures, such as the disease activity index (DAS) in rheumatoid arthritis, can provide advantages over individual measures to assess disease severity, analyse responses to therapy, and improve statistical power in a clinical trial or observational study.

Objectives To apply an index of four measures of severity of osteoarthritis of the hip or knee, the Western Ontario McMaster (WOMAC) scale, visual analogue scale (VAS) for pain, KellgrenLawrence radiographic stage, and number of joints involved among two hips and two knees, in analyses of results of a randomised, controlled clinical trial of diclofenac/misoprostol (Arthrotec, ARTH) compared to acetaminophen (ACET).

Methods 227 patients with radiographic stage 2-4 osteoarthritis of the hip or knee received either 6 weeks of ARTH $75 \mathrm{mg}$ twice a day or ACET $1,000 \mathrm{mg}$ four times a day after a washout period, and then the other drug for 6 weeks, in a randomised, double-blind, multicenter, crossover clinical trial. A pooled index to recognise patients who had mild osteoarthritis was developed according to 4 criteria: location in only one knee, Kellgren-Lawrence stage 2 , lowest tertile at screening for the WOMAC, and lowest tertile at screening for the pain VAS. The value of the pooled index was 0 (mildest) if 3 or 4 of the indicators applied to a patient; the value was 1 if 2 indicators applied to a patient, 2 if only one indicator applied to a patient, and 3 (most severe) if no indicator applied to a patient.

Results Overall, WOMAC pain scores were improved by 7.8 of 100 units $(\mathrm{p}<0.001)$, and pain VAS scores were improved by 14.6 of 100 units $(\mathrm{p}<0.001$ ), while taking ARTH versus ACET. Differences between changes in WOMAC scores while taking ARTH versus ACET were -0.8 (advantage to ACET) for 26 patients with a pooled index of $0(\mathrm{p}=0.86)$, compared to 1.5 (advantage to ARTH) for 50 patients with a pooled index of $1(\mathrm{p}=0.70), 6.8$ for 74 patients with a pooled index of $2(\mathrm{p}=$ $0.06)$, and 14.7 for 77 patients with pooled index of 3 ( $\mathrm{p}<$ 0.001). Differences between changes in pain VAS scores while taking ARTH versus ACET were 0.9 (advantage to ARTH) for patients with a pooled index of $0(\mathrm{p}=0.88)$, compared to 8.8 for patients with a pooled index of $1(\mathrm{p}=0.11), 14.0$ for patients with a pooled index of $2(\mathrm{p}=0.002)$, and 22.1 for patients with a pooled index of $3(\mathrm{p}<0.001)$.

Conclusion A pooled index of four measures of severity of osteoarthritis of the hip or knee, the WOMAC, pain VAS, Kellgran-Lawrence radiographic stage, and number of joints involved can be applied to analyse results of a clinical trial, and may be useful to stratify patients in clinical trials and clinical care.

\section{REFERENCE}

1 Goldsmith $\mathrm{CH}$, Smythe $\mathrm{HA}$, Helewa A. Interpretation and power of pooled index. J Rheumatol. 1993;20:575-8

\section{OP0050 IMMUNOGENETIC ASPECTS OF EROSIVE OSTEOARTHRITIS OF THE HAND}

R Ramonda, L Punzi, A Businaro, E Musacchio, F Schiavon, M Podswiadek, G Cardinale, $\mathrm{S}$ Todesco. Divisions of Rheumatology and Clinical Medicine, Department of Medical and Surgical Sciences, University of Padova, Padova, Italy

\subsection{6/annrheumdis-2001.417}

Background Erosive osteoarthritis of hand (EOA) is believed to be a subset of generalised OA characterised by frequent inflammatory episodes and an aggressive clinical course.

Objectives Since rare studies are available on the risk factors of EOA, we investigated its immunogenetic predisposition.

Methods In 47 patients with EOA (42 F, mean age $62.8 \pm 8$ years), HLA typing for A, B, C, DRB1 loci was performed. In the same patients we also evaluated the number of active joints (NAJ), the number of X-ray erosions (NEJ), the radiographic score (RS, Kallman), along with ESR and CRP.

Results The HLA antigens most frequently found in the 47 patients with EOA were A2 $(16=34 \%)$, B5 $(13=27.7 \%)$, Cw4 $(13=27.7 \%)$, and DRB1011 $(11=23.4 \%)$ and DRB103 $(8=17 \%)$. Interestingly, the frequency of these two latter antigens were higher in EOA than in non-EOA patients (DRB1011 